\title{
The potential impact of a recent measles epidemic on COVID-19 in Samoa
}

\author{
Chandini Raina Maclntyre ${ }^{1}$, Valentina Costantino ${ }^{*}$ (D) and David J. Heslop ${ }^{2}$
}

\begin{abstract}
Background: The pandemic of COVID-19 has occurred close on the heels of a global resurgence of measles. In 2019, an unprecedented epidemic of measles affected Samoa, requiring a state of emergency to be declared. Measles causes an immune amnesia which can persist for over 2 years after acute infection and increases the risk of a range of other infections.

Methods: We modelled the potential impact of measles-induced immune amnesia on a COVID-19 epidemic in Samoa using data on measles incidence in 2018-2019, population data and a hypothetical COVID-19 epidemic.

Results: The young population structure and contact matrix in Samoa results in the most transmission occurring in young people $<20$ years old. The highest rate of death is the $60+$ years old, but a smaller peak in death may occur in younger people, with more than $15 \%$ of total deaths in the age group under 20 years old. Measles induced immune amnesia could increase the total number of cases by $8 \%$ and deaths by more than $2 \%$.

Conclusions: Samoa, which had large measles epidemics in 2019-2020 should focus on rapidly achieving high rates of measles vaccination and enhanced surveillance for COVID-19, as the impact may be more severe due to measles-induced immune paresis. This applies to other severely measles-affected countries in the Pacific, Europe and elsewhere.
\end{abstract}

Keywords: Immune paresis, Measles immunity amnesia, Coronavirus

\section{Strengths and limitations of this study}

- This modelling study include heterogeneity of the Samoa population age structure and age specific contacts

- The model includes the effect of nonpharmaceutical interventions in containing the outbreak, like contacts tracing, quarantine, and isolation

- The force of infection is modelled to be heterogeneous over the infectious period

- The uncertain of the parameters used, especially regarding the infectiousness and proportion of

\footnotetext{
*Correspondence: vale.cost@protonmail.com

${ }^{1}$ The Biosecurity Program, The Kirby Institute, UNSW Medicine, The University of New South Wales, Sydney, Australia

Full list of author information is available at the end of the article
}

asymptomatic infections in the age group $<10$ years old is one of the limitations of this study.

\section{Background}

The pandemic of COVID-19 has occurred close on the heels of a global resurgence of measles. Europe, Asia and the Pacific have experienced unprecedented measles epidemics in 2019 [1]. Other than direct viral morbidity and mortality, measles causes an immune amnesia which can persist for over 2 years after acute infection and increases the risk of a range of other infections [2-6]. The mechanism is thought to be through loss of memory B cells and plasma cells which produce antibodies to a range of infections [7]. The measles virus is also shown to directly infect memory $\mathrm{CD} 4^{+}$and $\mathrm{CD} 8^{+} \mathrm{T}$ cells as well as naïve $T$ cells [8]. A study in Switzerland showed that measles immune amnesia increases the risk of a wide 
range of infections, with a relative risk of 3.47 for other infections following measles [2]. This risk may be higher in low income countries where malnutrition is an exacerbating factor. The corollary is that measles vaccination can protect against non-measles infections, presumably by preventing immune dysfunction [9]. In the Democratic Republic of Congo, measles vaccine protected against fever, cough and diarrhoea, presumably of non-measles causes [10].

In 2019, an unprecedented epidemic of measles affected Samoa. A state of emergency was declared on November 15th and lifted on December 2019, with a peak of the epidemic around November 26th and up to $3 \%$ of the population infected (5707 cases of 199,955 people) with 87 deaths [11]. The highest rates of infection were in the age groups $6-11$ months, $0-5$ months and 1-4 years, with $87 \%$ of deaths in children under 5 years. This translates to $8 \%$ of the population under 15 years being infected with measles within the last 6 months [12]. Over $35 \%$ of the Samoan population $(70,694)$ is aged $<15$ years, and only $5.2 \%$ is over 65 years old.

Based on available data, COVID-19 causes more severe illness in older people, and children may be asymptomatic, especially under the age of $10[13,14]$. However, in a case series of over 2000 children with COVID-19, only $50 \%$ had mild infection, $6 \%$ had critical illness and 1 child aged 14 years died [15]. In another case series, a child aged 10 months died of COVID-19 [16].

We previously exercised a hypothetical pandemic in the Pacific, with involvement of multiple Pacific island nations, and highlighted the unique challenges of the region [17]. These include multiple islands, small populations, natural disasters, weak health systems and poor disease surveillance infrastructure [18]. The impact of measles induced immune amnesia on the manifestation of COVID-19 is unknown and has not been considered, despite a global resurgence of measles in 2019. COVID19 in Samoa could have a severe impact and a disproportionate increase in morbidity and mortality due the medium-term immune dysregulation caused by the recent measles epidemic.

The aim of this study is to estimate the age-specific morbidity and mortality impact of COVID-19 in Samoa, accounting for the potential impact of measles-induced immune amnesia.

\section{Methods}

We used data from the WHO situation reports of the measles epidemic in Samoa [11, 19, 20], and an assumption that immune amnesia would be present in children infected from November 2019 onward for at least 12 months and up to 36 months [2], to model the morbidity and mortality impact of a COVID-19 epidemic in the country. We used the Samoa population for 2020 [21], which we divided by age groups following the age distribution in 2016 [22].

The entire population was considered susceptible to COVID-19 and the hypothetical epidemic starts at $\mathrm{t}=1$ with 6 latently infected people. After symptom onset, we assumed that only $80 \%$ of symptomatic infected people get effectively isolated after 5 days [23], and isolation is assumed to stop further transmission. However asymptomatic cases, assumed to be $35 \%$ of all infections [2426] will not be isolated because they will not be detected due to weak health systems and limited testing capacity in Samoa. Detection of asymptomatic cases requires substantially expanded testing capacity and testing of all close contacts of a case, regardless of symptoms - this is unlikely in small Pacific islands, which may struggle to even test all symptomatic cases. We considered the latent or asymptomatic period to be infectious during the last 2 days before symptoms onset, causing $44 \%$ of the total transmissions [27], and assumed the highest viral load just prior to and just after symptoms [26, 28-31]. Regarding the symptomatic period, we modelled the first day as the most infective, following by a decreasing in the transmissions potential for the following 6 days [27], making the infectious symptomatic period 7 days long [30]. Accounting for weak health systems and limited human resource capacity, we assumed that only $60 \%$ of known contacts of an infected person will be quarantined for 14days, and if they are latent and become symptomatic, they will take 2 days to be isolated, however we assumed that only $80 \%$ of symptomatic people will be effectively isolated without further transmissions.

We used an age-specific deterministic model which simulates the epidemic in Samoa running for 400 days. The model moves people between 13 mutually exclusive compartments: Susceptible (S), Latent not infectious (E), Latent infectious undiagnosed $(\mathrm{Eu})$ and diagnosed $(\mathrm{Et})$, first symptomatic day for undiagnosed (I1) and diagnosed (I2), following 6 days of symptomatic for undiagnosed (I11) and diagnosed (I22), Asymptomatic infectious stages (A1 and A2), Isolated (Q), Recovered (R) and Dead (D). Each of those compartments is divided in 16 age stratified groups each of 5 years duration, ranging from 0 to 74 years old plus an additional age group of $75+$ years, as available from the population data for Samoa. The force of infection that moves people from the susceptible compartment to the latent one is age-specific, based on average age-specific contact rates for Samoa [32], the R0 and the proportion of infected people over the entire population.

We considered transmission to be the same in adults and children based on viral shedding data that suggest this [33], where children often present very milder symptom or none [34-36]. Studies showed children under 5 years have a higher viral load in the respiratory tract 
than adults or older children [37-39]. Another study showed that COVID-19 attack rates in families were higher when the primary case was a child [40]. In the United States, 9.8\% of all cases of COVID-19 were children [41]. Given the role of children in transmission remains an area of uncertainty, we conservatively assumed equal transmission potential from children and adults. Failure to seroconvert has also been documented in people with asymptomatic infection [42], so lack of seropositivity may not equate to lack of infection, as infection may be asymptomatic or mild may not result in seroconversion in children $<10$ years [43].

To include the effect of measles on the immune system of COVID-19 infected people, we used the total number of reported cases of measles in 2019 in Samoa, 5707 [11] and, due to the lack of detailed individual age data for those cases, we assumed that $90 \%$ were in the first age-group $0-4$ years, $5 \%$ in the $5-9$ age group and $5 \%$ in the 10-14 age group, based on the data showing that $87 \%$ of all deaths were reported in the age-group younger than 5 [11]. Once we distributed cases in those three age groups, we calculated the proportion of people that had measles with respect to the age group size.

Based on a three-year observational study, immunological amnesia after measles can increase the risk of infectious disease hospitalizations by 3.47 times [2]. For the people who had been infected with measles in the preceding 12 months, we than assumed that they are 3.47 times more likely to get infected with COVID-19. However, we averaged the susceptibility of each agegroup, weighting it between the proportion that had measles against those that did not, and overall calculated that the first three age groups, $0-4,5-9$ and $10-14$ are $1.44,1.03$ and 1.03 times more likely to get infected respectively. Model parameters are shown in Table 1, while the model equations are described in the supplementary material.

\section{Patient and public involvement}

No patients were involved in the design of this study, development of research questions and outcome measures.

\section{Data sharing}

No additional data available.

\section{Results}

In Fig. 1 we show the age distribution of infections on the left and deaths on the right by the end of the epidemic. With or without measles effect, about $60 \%$ of infections are in the age group younger than 20 years old. Without the measles effect, 11.76, 17.33, 16.42 and $14.18 \%$ of the total cases are in the age group 0-4, 5-9, 10-14 and 15-19 respectively, with deaths in the under 20 years old accounting for more than $15 \%$ of the total
Table 1 Parameters used in the model

\begin{tabular}{|c|c|c|}
\hline Parameter & Value & Source \\
\hline $\begin{array}{l}\text { Basic reproduction } \\
\text { number }\end{array}$ & 2.5 & [26] $\{L i, 2020 \# 5\}$ \\
\hline Infectious period & $\begin{array}{l}9 \text { days of which } 2 \text { in } \\
\text { latency and } 7 \\
\text { symptomatic }\end{array}$ & {$[27]$} \\
\hline $\begin{array}{l}\text { Increased susceptibility to } \\
\text { COVID-19 due to measles }\end{array}$ & $\begin{array}{l}1.44 \text { for } 0-4 \text { years old } \\
1.03 \text { for } 5-9 \text { years old } \\
1.03 \text { for } 10-14 \text { years old }\end{array}$ & Calculated \\
\hline $\begin{array}{l}\text { Time to isolation once } \\
\text { symptomatic }\end{array}$ & 5 days & [44] \\
\hline $\begin{array}{l}\text { Effectiveness of home } \\
\text { quarantine in latency } \\
\text { period }\end{array}$ & $50 \%$ reduction in the $\mathrm{R} 0$ & {$[45]$} \\
\hline Effectiveness of isolation & 100\% (no transmissions) & \\
\hline $\begin{array}{l}\text { Duration of home } \\
\text { quarantine }\end{array}$ & 14 days & $\begin{array}{l}\text { WHO } \\
\text { recommendation } \\
{[46]}\end{array}$ \\
\hline Duration of isolation & 14 days & \\
\hline $\begin{array}{l}\text { Proportion of } \\
\text { asymptomatic or very } \\
\text { mild infectious }\end{array}$ & $35 \%$ & {$[24-26]$} \\
\hline $\begin{array}{l}\text { Proportion of contacts } \\
\text { identified for home } \\
\text { quarantine }\end{array}$ & $60 \%$ & [23] \\
\hline $\begin{array}{l}\text { Proportion of } \\
\text { symptomatic people that } \\
\text { get isolated after } 5 \text { days }\end{array}$ & $80 \%$ & [23] \\
\hline $\begin{array}{l}\text { Age-specific case fatality } \\
\text { rate (\%) for the } 16 \text { age } \\
\text { groups }\end{array}$ & $\begin{array}{l}0.1,0.1,0.2,0.2,0.2,0.2, \\
0.2,0.2,0.4,0.4,1.3,1.3, \\
3.6,3.6,8,14.8\end{array}$ & {$[47]$} \\
\hline
\end{tabular}

deaths. Most deaths occur in older age groups. With measles immune paresis, the proportion of cases in the age group 0-4 represents $15.55 \%$ of the total cases and in the following two age-groups it is 16.69 and $15.57 \%$ of the total number of cases, respectively. Measles immune paresis increases the number of cases by $42 \%$ in the first age group (from 10,680 cases to 15,213), almost $4 \%$ in the second age group and just over $2 \%$ in the third age group; while deaths in the age group 0-4 see a $59 \%$ increase (from 17 to 27). This corresponds to an increase of almost $8 \%$ (from 90,784 to 97,824 ) in the total number of cases and an increase of 2.3\% (from 901 to 944) in the number of total deaths associated with measles immune paresis (Fig. 2).

\section{Discussion}

The population of Samoa has experienced a recent, severe measles epidemic, and as of the end of June 2020 not yet reported any cases of COVID-19. The impact of measles immune paresis is well documented $[2,4,7,8$, 48], but has not been considered as a factor which may influence COVID-19 epidemiology to date. In the first study considering this, we show a potential increase of 

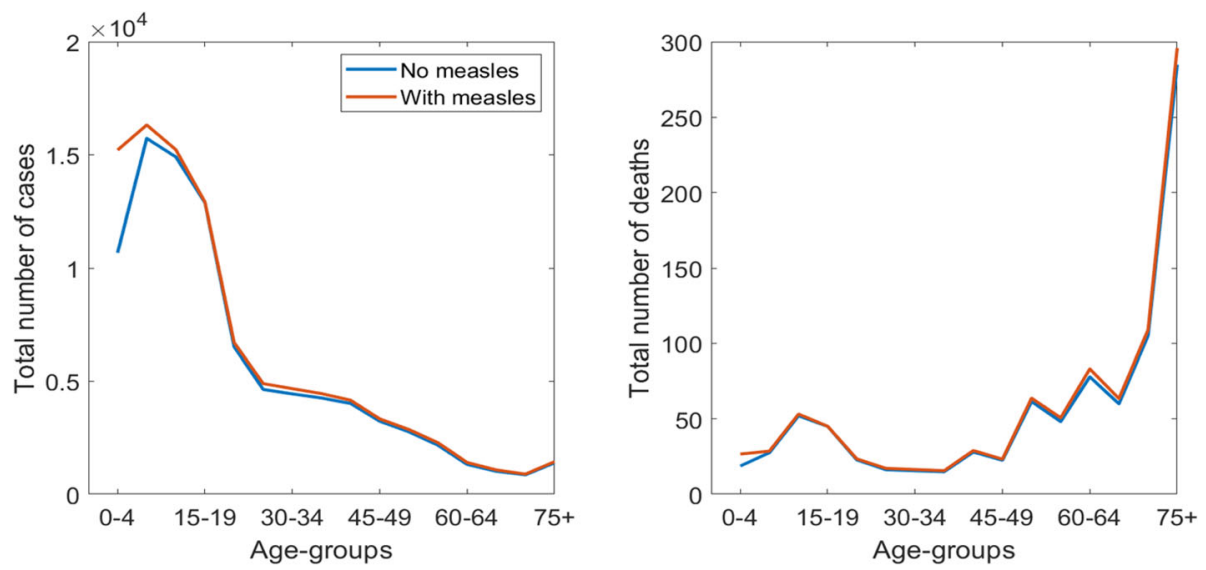

Fig. 1 Cumulative age-specific cases (left) and deaths (right) with and without measles immunity paresis effect

morbidity and mortality following the spread of COVID19 in Samoa. The immune effects of measles would be most prevalent in the most measles-affected age group in Samoa, children, resulting in potential increases in morbidity and mortality in this age group. Samoa has a young age structure and intense contact between younger age groups driving the observed COVID-19 transmission in the model, and this is compounded by the high attack rate of measles in children in 2019. A large proportion of infection in children is asymptomatic or mild, with the probability of symptomatic disease increasing with age. However, available data show that severe morbidity and mortality can occur in children [15]. Deaths due to COVID-19 have been documented in infants [16]. The effect of the severe measles epidemic may result in higher severity of disease in children in Samoa. It is also now clear based on viral shedding data that children play an important role in transmission [33], and may even have a higher viral load in the respiratory tract than adults [37]. A household contact study found that COVID-19 attack rates in families were higher when the primary case was a child [40].

The age specific mixing rates in most countries show a peak in social mixing in young people and children, corresponding to increased infection transmission for most infections in these age groups [32, 49]. Therefore, if COVID-19 is introduced into Samoa, children and young people may drive transmission, which could place older people at risk due to extended family structures and the importance of community gatherings in Pacific islands. There are few data on COVID-19 in the Pacific, but one study reports poorer outcomes in Pacific Islanders in Hawaii, attributed to lifestyle diseases and comorbidities such as diabetes [50].

For these reasons, prevention and control of COVID19 in Samoa is critical. Disease control measures such as travel bans, case isolation, contact tracing, quarantine, face masks and social distancing are the only available interventions for COVID-19 at this time, and Samoa has effectively closed its international borders [23]. For a
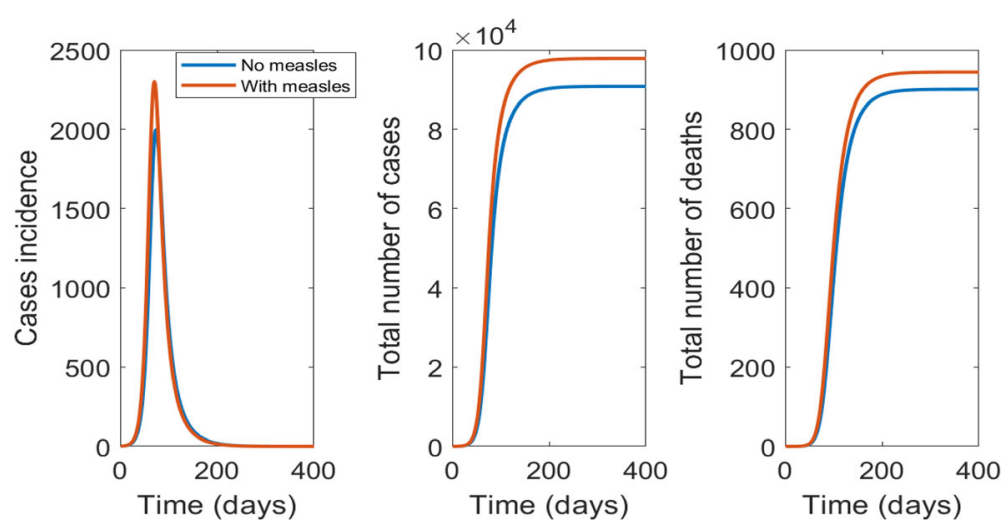

Fig. 2 From left to right: cases incidence, cumulative cases and deaths with and without measles immunosuppression 
young population like Samoa, school closure would be an effective disease control strategy for both measles and COVID-19 [32]. Social distancing may be particularly difficult in Pacific cultures, where large gatherings and extended families are the norm, so face mask use should be considered. Ensuring high levels of vaccination against measles is also critical to reduce the potential additional risk of measles immune paresis.

A study of 2143 paediatric cases in China found only $50 \%$ had mild disease, 30\% had moderate disease, $6 \%$ were critically ill and one child aged 14 years died [15]. In another study, of 171 cases of COVID-19 in China, the median age was 6.7 years, three required ventilation and an infant aged 10 months died [16]. This accumulating evidence, including recent association with Kawasaki disease, shows that severe illness and death is possible in children. The occurrence of post-COVID-19 Multisystem Inflammatory Syndrome, or Kawasaki Syndrome, in children with a median age of 8 years, is associated with high morbidity and mortality [51], but the impact of this syndrome was not considered in the model. It is unknown whether measles immune paresis would reduce or increase the risk of Kawasaki disease after COVID-19 infection, but research is warranted in this area.

\section{Conclusions}

Whilst children may be more likely to be asymptomatically infected, reflected by a low proportion of all cases being children [47] a background of a compromised immune system induced by recent measles infection may change the age-specific epidemiology in countries with recent, widespread measles transmission. These considerations may also affect other countries which have had recent measles epidemics in the Pacific, in Europe and elsewhere. These countries must strongly focus on achieving high levels of measles vaccination as part of the COVID-19 control strategy.

\section{Supplementary information}

Supplementary information accompanies this paper at https://doi.org/10. 1186/s12879-020-05469-7.

\section{Additional file 1 .}

\section{Acknowledgements}

Not applicable.

\section{Authors' contributions}

C R M: ideology, model parametrization, literature searching, writing, and reviewing. V C: model builder, writing and reviewing. D H: reviewing. The author(s) read and approved the final manuscript.

\section{Funding}

Raina Maclntyre is supported by a NHMRC Principal Research Fellowship, grant number 1137582 .

\section{Availability of data and materials}

For measles cases in Samoa, this study uses open access published data available from WHO reports at https://www.who.int/immunization/ monitoring_surveillance/burden/vpd/surveillance_type/active/measles_ monthlydata/en/, while to inform the model for the spread of COVID-19 in Samoa we used previously estimated parameters from literature. All data used are open access.

\section{Ethics approval and consent to participate}

This study is a modelling study which uses open access published data and does not contain any individual or identifying data. As such, no ethics approval or any administrative permissions and/or licenses were acquired by my team to access the data used in our research.

Consent for publication

Not applicable.

\section{Competing interests}

Authors declare no conflict of interests for this work.

\section{Author details}

${ }^{1}$ The Biosecurity Program, The Kirby Institute, UNSW Medicine, The University of New South Wales, Sydney, Australia. ${ }^{2}$ School of Public Health and Community Medicine, The University of New South Wales, Sydney, Australia.

Received: 7 July 2020 Accepted: 1 October 2020

Published online: 07 October 2020

References

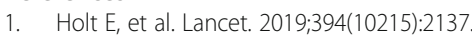

2. Behrens $L$, Cherry JD, Heininger U. The susceptibility to other infectious diseases following measles during a three year observation period in Switzerland. Pediatr Infect Dis J. 2020:39(6):478-82.

3. Laksono BM, de Vries RD, Duprex WP, de Swart RL. Measles pathogenesis, immune suppression and animal models. Curr Opin Virol. 2020;41:31-7 Available from: https://pubmed.ncbi.nlm.nih.gov/32339942/. [cited $2020 \mathrm{Jul} 1$ ].

4. Ayasoufi K, Pfaller CK. Seek and hide: the manipulating interplay of measles virus with the innate immune system. Curr Opin Virol. 2020;41:18-30 Available from: https://pubmed.ncbi.nlm.nih.gov/32330821/. [cited 2020 Jul 1].

5. Mina MJ, Grenfell BT, Jessica E, Metcalf C. Response to Comment on "Longterm measles-induced immunomodulation increases overall childhood infectious disease mortality". Science. 2019;365 Available from: https:// pubmed.ncbi.nlm.nih.gov/31296742/. [cited 2020 Jul 1].

6. Mina MJ, Metcalf CJE, De Swart RL, Osterhaus ADME, Grenfell BT. Long-term measles-induced immunomodulation increases overall childhood infectious disease mortality. Science. 2015;348(6235):694-9 Available from: https:// pubmed.ncbi.nlm.nih.gov/25954009/. [cited 2020 Jul 1].

7. Mina $T$, Leng $Y$, et al. MK. Measles virus infection diminishes preexisting antibodies that offer protection from other pathogens. Science. 2019;366: 599-606.

8. Laksono BM, de Vries RD, Verburgh RJ, Visser EG, de Jong A, Fraaij PLA, et al. Studies into the mechanism of measles-associated immune suppression during a measles outbreak in the Netherlands. Nat Commun. 2018;9(1):1-10 Available from: https://www.nature.com/articles/s41467-018-07515-0. [cited 2020 Jul 1].

9. Mina MJ. Measles, immune suppression and vaccination: direct and indirect nonspecific vaccine benefits. J Inf Secur. 2017:74:S10-7.

10. Ashbaugh JD, Hoff NA, et al. Association of previous measlesinfection with markers of acute infectious disease among 9- to 59-monthold children in the Democratic Republic of the Congo. J Pediatr Infect Dis Soc. 2018;8:531-8.

11. WHO. MEASLES OUTBREAK IN THE PACIFIC-SITUATION REPORT No. 11 Joint WHO/UNICEF Measles Outbreak Response and Preparedness in the Pacific Event highlights. 2020

12. Countrymeters. Samoa population. 2020. 2020. Available from: https:// countrymeters.info/en/Samoa\#population_2019. Accessed 24 Mar 2020.

13. Chan JF-W Yuan S, Kok K-H, To KK-W, Chu H, Yang J, et al. A familial cluster of pneumonia associated with the 2019 novel coronavirus indicating person-to-person transmission: a study of a family cluster. Lancet. 2020; 395(10223):514-23. https://doi.org/10.1016/S0140-6736(20)30154-9. 
14. Li Q, Guan X, Wu P, Wang X, Zhou L, Tong Y, et al. Early transmission dynamics in Wuhan, China, of novel coronavirus-infected pneumonia. N Engl J Med. 2020;382(13):1199-207. https://doi.org/10.1056/NEJMoa2001316.

15. Dong Y, Mo X, Hu Y, Qi X, Jiang F, Jiang Z, et al. Epidemiological Characteristics of 2143 Pediatric Patients With 2019 Coronavirus Disease in China. Pediatrics. 2020; Available from: http://www.ncbi.nlm.nih.gov/ pubmed/32179660. [cited 2020 Mar 25].

16. Lu X, Zhang L, Du H, Zhang J, Li YY, Qu J, et al. SARS-CoV-2 Infection in Children. N Engl J Med. 2020;18:NEJMc2005073 Available from: http://www. nejm.org/doi/10.1056/NEJMc2005073. [cited 2020 Mar 25].

17. Maclntyre C, Heslop D, Nand D, Schramm C, Butel M, Rawlinson W, et al. Exercise Mataika: White Paper on response to a smallpox bioterrorism release in the Pacific. Glob Biosecurity. 2019;1 (1):91-105. https://doi.org/10. 31646/gbio.10.

18. Hassan M, Stewart T, Maclntyre CR. SK. The ARM network--a model for infectious disease surge response capacity in the Western Pacific region. West Pac Surveill Response J. 2014;16(5):2-5.

19. (WHO) WHO. MEASLES OUTBREAK IN THE PACIFIC - SITUATION REPORT No. 9. Joint WHO/UNICEF Measles Outbreak Response and Preparedness in the Pacific. 2019; Available from: https://www.who.int/docs/default-source/ wpro\%2D\%2D-documents/dps/outbreaks-and-emergencies/measles-2019/ measles-pacific-who-unicef-sitrep-20200103.pdf?sfvrsn=82f90381_2. Accessed 24 Mar 2020

20. WHO. WHO | Measles and Rubella Surveillance Data. Geneva: WHO; 2020.

21. POPULATION \& DEMOGRAPHY INDICATOR SUMMARY. Available from: https://www.sbs.gov.ws/population. [cited 2020 Mar 24].

22. Statistical Abstract 2017.-Apia, Samoa: Social Statistics Division, Samoa Bureau of Statistics (SBS). 2018. p. 96.

23. Maclntyre Valentina; Kunasekaram, Mohana Priya CRC. Health system capacity in Sydney,Australia in the event of a biological attack with smallpox. PLoS One. 2019;14(6):e0217704. https://doi.org/10.1371/journal. pone.0217704

24. Mizumoto K, Chowell G. Transmission potential of the novel coronavirus (COVID-19) onboard the diamond princess cruises ship, 2020. Infect Dis Model. 2020;5:264-70.

25. Estimating the asymptomatic ratio of 2019 ... | Oxford Martin School. Available from: https://www.oxfordmartin.ox.ac.uk/publications/estimatingthe-asymptomatic-ratio-of-2019-novel-coronavirus-onboard-the-princesscruises-ship/. [cited 2020 Mar 24].

26. COVID-19 Pandemic Planning Scenarios | CDC. Available from: https://www. cdc.gov/coronavirus/2019-ncov/hcp/planning-scenarios.html. [cited 2020 Jun 29].

27. He X, Lau EHY, Wu P, Deng X, Wang J, Hao X, et al. Temporal dynamics in viral shedding and transmissibility of COVID-19. Nat Med. 2020;26(5):672-5.

28. Lin Y, Xie B, et al. Asymptomatic Novel Coronavirus Pneumonia Patient Outside Wuhan: The Value of CT Images in the Course of the Disease. Clin Imaging. 2020;63:7-9.

29. Rothe M, Sothmann P, et al. Transmission of 2019-nCoV Infection from an Asymptomatic Contact in Germany. N Engl J Med. 202;382(10):970-1. https://doi.org/10.1056/NEJMc2001468.

30. Zou L, Ruan F, Huang M, Liang L, Huang H, Hong Z, et al. SARS-CoV-2 Viral Load in Upper Respiratory Specimens of Infected Patients. N Engl J Med. 2020; Available from: https://www.nejm.org/doi/full/10.1056/NEJMc2001737. Accessed 24 Mar 2020.

31. Du Z, Xu X, Wu Y, Wang L, Cowling BJ, Meyers LA. Serial Interval of COVID19 among Publicly Reported Confirmed Cases. Emerg Infect Dis. 2020;26(6) Available from: http://www.ncbi.nlm.nih.gov/pubmed/32191173. [cited 2020 Mar 24].

32. Prem $\mathrm{K}$, Cook AR, Jit M. Projecting social contact matrices in 152 countries using contact surveys and demographic data. PLoS Comput Biol. 2017 Sep 1;13(9):e1005697.

33. Han MS, Choi EH, Chang SH, Jin B-L, Lee EJ, Kim BN, et al. Clinical Characteristics and Viral RNA Detection in Children With Coronavirus Disease 2019 in the Republic of Korea. JAMA Pediatr. 2020. Available from: http://www.ncbi.nlm.nih.gov/pubmed/32857112. [cited 2020 Sep 8].

34. Ludvigsson JF. Systematic review of COVID-19 in children shows milder cases and a better prognosis than adults. Acta Paediatr Int J Paediatr. 2020; 109:1088-95 Available from: https://onlinelibrary.wiley.com/doi/full/10.1111/ apa.15270. [cited 2020 Sep 16].
35. Dong Y, Dong Y, Mo X, Hu Y, Qi X, Jiang F, et al. Epidemiology of COVID-19 among children in China Pediatrics145 2020 p. 20200702. Available from: https://doi.org/10.1542/peds.2020-0702. [cited 2020 Sep 16].

36. Kelvin AA, Halperin S. COVID-19 in children: the link in the transmission chain. Lancet Infect Dis. 2020;20:633-4 Available from: https://science. sciencemag.org/content/367/6482/1061? r. [cited 2020 Sep 16].

37. Heald-Sargent T, Muller WJ, Zheng X, Rippe J, Patel AB, Kociolek LK. AgeRelated Differences in Nasopharyngeal Severe Acute Respiratory Syndrome Coronavirus 2 (SARS-CoV-2) Levels in Patients With Mild to Moderate Coronavirus Disease 2019 (COVID-19). JAMA Pediatr. 2020;30 Available from: https://jamanetwork.com/journals/jamapediatrics/fullarticle/2768952. [cited 2020 Sep 8].

38. Zachariah P, Halabi KC, Johnson CL, Whitter S, Sepulveda J, Green DA. Symptomatic Infants have Higher Nasopharyngeal SARS-CoV-2 Viral Loads but Less Severe Disease than Older Children. Clin Infect Dis. 2020; Available from: https:/www.ncbi.nlm.nih.gov/pmc/articles/PMC7314126/. [cited 2020 Sep 16].

39. Kam KQ, Yung CF, Cui L, Tzer Pin Lin R, Mak TM, Maiwald M, et al. A Well Infant With Coronavirus Disease 2019 With High Viral Load. Clin Infect Dis. 2020;71(15):847-9 Available from: https://www. [cited 2020 Sep 16].

40. Lopez Bernal J, Panagiotopoulos N, Byers C, Garcia Vilaplana T, Boddington $\mathrm{N}$, Zhang X-S, et al. Transmission dynamics of COVID-19 in household and community settings in the United Kingdom. medRxiv 2020;2020.08.19. 20177188. Available from: https://doi.org/10.1101/2020.08.19.20177188. [cited 2020 Sep 8].

41. American Academy of Pediatrics 2020; Children and COVID-19:State-Level Data Report. Accessed at AAP at https:/services.aap.org/en/pages/2019novel-coronavirus-covid-19-infections/children-and-covid-19-state-level-datareport/.

42. Yongchen Z, Shen H, Wang X, Shi X, Li Y, Yan J, et al. Different longitudinal patterns of nucleic acid and serology testing results based on disease severity of COVID-19 patients. Emerg Microbes Infect. 2020;9(1):833-6 Available from: https://www.tandfonline.com/doi/full/10.1080/22221751.202 0.1756699. [cited 2020 Jun 30].

43. Gudbjartsson DF, Helgason A, Jonsson H, Magnusson OT, Melsted P, Norddahl GL, et al. Spread of SARS-CoV-2 in the Icelandic Population. N Engl J Med. 2020;382(24):2302-15 Available from: http://www.nejm.org/ doi/10.1056/NEJMoa2006100. [cited 2020 Jun 30].

44. Wang D, Hu B, Hu C, Zhu F, Liu X, Zhang J, et al. Clinical Characteristics of 138 Hospitalized Patients With 2019 Novel Coronavirus-Infected Pneumonia in Wuhan, China. JAMA. 2020. https://doi.org/10.1001/jama.2020.1585.

45. Zhang S, Diao MY, Yu W, Pei L, Lin Z, Chen D. Estimation of the reproductive number of novel coronavirus (COVID-19) and the probable outbreak size on the diamond princess cruise ship: a data-driven analysis. Int J Infect Dis. 2020;93:201-4.

46. Advice for public. Available from: https://www.who.int/emergencies/ diseases/novel-coronavirus-2019/advice-for-public. [cited 2020 Mar 27].

47. Team TNCPERE. Vital surveillances: the epidemiological characteristics of an outbreak of 2019 novel coronavirus diseases (COVID-19) - China, 2020. China CDC Wkly. 2020;2(8):113-22.

48. Du Toit A. Measles increases the risk of other infections. Nat Rev Microbiol. 2020;18:2.

49. Mossong J, Hens N, Jit M, Beutels P, Auranen K, Mikolajczyk R, et al. Social contacts and mixing patterns relevant to the spread of infectious diseases. PLoS Med. 2008;5(3):e74 Available from: http://journals.plos.org/ plosmedicine/article?id=10.1371/journal.pmed.0050074. [cited 2015 Nov 3].

50. Kaholokula JK aimoku, Samoa RA, Miyamoto RES, Palafox N, Daniels SA. COVID-19 Special Column: COVID-19 Hits Native Hawaiian and Pacific Islander Communities the Hardest. Hawai'i J Heal Soc Welf. 2020. 79(5):1446. Available from: https://www.ncbi.nlm.nih.gov/pmc/articles/PMC7226312/. [cited 2020 Jun 30].

51. Feldstein LR, Rose EB, Horwitz SM, Collins JP, Newhams MM, Son MBF, et al. Multisystem Inflammatory Syndrome in U.S. Children and Adolescents. N Engl J Med. 2020;NEJMoa2021680. Available from: http://www.nejm.org/ doi/10.1056/NEJMoa2021680. [cited 2020 Jul 1].

\section{Publisher's Note}

Springer Nature remains neutral with regard to jurisdictional claims in published maps and institutional affiliations. 